\title{
Rethinking resting eggs decapsulating
}

\author{
Repensando o decapsulamento de ovos de resistência
}

Marina Isabela Bessa da Silva ${ }^{1}$ (D), Déborah Maria de Oliveira $^{1}$ (D), Luciana Pena Mello Brandão ${ }^{1 *}$ (D), Francisco Antônio Rodrigues Barbosa ${ }^{1}$ (D) and Paulina Maria Maia-Barbosa ${ }^{1}$

\begin{abstract}
${ }^{1}$ Laboratório de Limnologia, Ecotoxicologia e Ecologia Aquática - Limnea, Instituto de Ciências Biológicas, Universidade Federal de Minas Gerais - UFMG, Av. Antonio Carlos, 6627, Pampulha, Belo Horizonte, MG, Brasil

*e-mail: lucianapmb@hotmail.com
\end{abstract}

Cite as: Silva, M.I.B. et al. Rethinking resting eggs decapsulating. Acta Limnologica Brasiliensia, 2019, vol. 31, e28.

Abstract: Aim: Temperature and light have been recognized as important factors for ephippia hatching in temperate and tropical freshwater systems. Oddly some authors suggested that decapsulation of resting eggs would be a pro when it comes to ex situ hatching studies, exposing those eggs to a greater amount of light. This study aimed to compare the difference in the hatching rate between resting eggs decapsulated and intact ephippia of Daphnia laevis, a zooplankton that occurs at lakes, in tropical freshwaters (Cladocera). Methods: The ephippia used in this work were collected at the sediment of a reservoir, in Belo Horizonte city (Minas Gerais, Brazil). We set up the laboratory experiment with two distinct groups: intact ephippia and decapsulated resting eggs. For that, we manually decapsulated 120 ephippia and kept 120 others intact (six replicas with 20 ephippia each), then incubated them all with culture water at $22^{\circ} \mathrm{C}(12 \mathrm{~h}$ photoperiod) for 30 days with daily monitoring. Results: The results showed that decapsulation influenced negatively the hatching success, as the intact ephippia had a hatching rate of $22 \%$, while those decapsulated only had $6 \%$. In addition, Daphnia hatchlings were observed for intact ephippia group up to the twenty-seventh day, while for the decapsulated the last hatching occurred on the tenth day. Decapsulated eggs are subject to high exposure to light and it may jeopardize the embryo development. Conclusions: In this context, we suggest that removing the protective capsule from the eggs needs to be done with caution, since in some species this can damage the resting eggs, which alters the viability and compromise the accuracy of the hatching rates studies.

Keywords: Daphnia laevis; ephippia; diapause; hatching rates; zooplankton.

Resumo: Objetivo: Temperatura e luz são reconhecidas como importantes fatores para eclosão de efípios em sistemas dulcícolas tropicais e temperados. Curiosamente, alguns autores sugerem que remover a cápsula dos ovos de resistência seria um benefício quando se trata de estudos de eclosão ex situ, expondo esses ovos a uma maior quantidade de luz. Este estudo teve como objetivo comparar a diferença na taxa de eclosão entre os ovos de resistência descapsulados e efípios intactos de Daphnia laevis, (Cladocera) que ocorre em lagos tropicais. Métodos: Os efípios utilizados neste trabalho foram coletados no sedimento de um reservatório na cidade de Belo Horizonte (Minas Gerais, Brasil). O experimento foi realizado em laboratório com dois grupos distintos: efípios intactos e ovos de resistência descapsulados. Para isso, descapsulamos manualmente 120 efípios e mantivemos outros 120 intactos (seis réplicas com 20 efípios cada) e incubamos todos a $22^{\circ} \mathrm{C}$ (fotoperíodo de $12 \mathrm{~h}$ ) por 30 dias, fazendo monitoramento diário. Resultados: Os resultados mostraram que o decapsulamento influenciou negativamente o sucesso da incubação, uma vez que os efípios intactos apresentaram 
$22 \%$ de taxa de eclosão, e os descapsulados, apenas 6\%. Além disso, até o vigésimo sétimo dia foi observado nascimento de Daphnias do grupo com efípios intactos, enquanto que para o grupo de ovos descapsulados, a última eclosão ocorreu no décimo dia. Os ovos descapsulados estão sujeitos à alta luminosidade que pode comprometer o desenvolvimento do embrião. Conclusóes: Neste contexto, sugerimos que a remoçáo da cápsula protetora dos ovos seja feita com cautela, pois em algumas espécies isso pode danificar os ovos de resistência, alterando a viabilidade e comprometendo a exatidão dos estudos com taxas de eclosão.

Palavras-chave: Daphnia laevis; efípios; diapausa; taxas de eclosão; zooplâncton.

\section{Introduction}

Different survival strategies of species in nature are determinant for the maintenance of their populations. A great example of these mechanisms is diapause, a temporary retention on development, controlled by endogenous physiological factors, that may involve a metabolism decrease. It is present in at least one specie in almost all animal phyla. In aquatic ecosystems, it consists of the production of resting eggs from some zooplankton species. These eggs are produced when environmental conditions are not suitable, or when any genetic factors for their production are involved and generally try to avoid extinction (Fryer, 1996; Brendonck \& De Meester, 2003). Organisms of the genus Daphnia keep their resting eggs protected by the modified carapace of the mother called ephippium, that may indicate extra protection from the external environment (Retnaningdyah \& Ebert, 2016). Some of these dormant structures may float on the lake water column, while others sink in the lake sediment - which contributes to the buildup and dispersal of the so-called egg bank (Cáceres $\&$ Tessier, 2004).

Daphnia species are an important source of food for fish and invertebrates (Haghparast et al., 2012). As important planktonic herbivores, these organisms are also considered key species in lentic ecosystems. The populations of Daphnia are usually formed by females that reproduce through parthenogenesis, generating other females by this mechanism. When there are any unfavorable signs for the species, such as fluctuations in temperature (Jersabek \& Schabetsberger, 1995), abrupt increases in population density (King \& Snell, 1980; Ban \& Minoda, 1992), seasonal changes (Brandão et al., 2014), predation pressure (Slusarczyk, 1995; Pijanowska \& Stolpe, 1996), food scarcity (Gilbert, 1995), photoperiod and competition changes (Gilbert \& Williamson, 1983), exposure to aquatic contaminants (Portinho et al., 2018) or a combination of these factors (Kleiven et al., 1992), these females begin to produce ephippia. These can be produced by sexual (in cyclical populations) or asexual reproduction (in obligate parthenogenetics populations) (Innes \& Singleton, 2000). Both types of populations (obligates and cyclical populations) can produce empty ephippia due to the absence of male fertilization or eggs abortion (Larsson, 1991).

The ephippia contained in the sediment do not hatch all at the same time, which allows generation overlapping and reduces the risk of extinctions. (Hairston Junior et al.1995). The interdependence between the hatching time of each ephippium at the egg bank and the active plankton population increases the dynamics and the genetic variability in many species that have this type of mechanism (Möst et al., 2015). In this context, many are the stimuli that trigger an ephippia hatching, and the most known and studied are changes in light availability and temperature (Stross, 1966; Hairston Junior et al., 2000; Vandekerkhove et al., 2005; Paes et al., 2016). Studies on the diapause of cladocerans in South America only began 15 years ago, and experiments using tropical species are needed to improve the knowledge of dormancy strategies (Iglesias et al., 2016).

Like the stimuli, the hatching rates also vary between species and within the same species. The number of resting eggs present within the ephippium also varies, and may contain one, two, three eggs or be empty (Zaffagnini, 1987; Paes et al., 2015). Recent studies have shown that a large percentage of the ephippia are completely empty (Vaníčková et al., 2010; Conde-Porcuna et al., 2011; Ohtsuki et al., 2015; Paes et al., 2016; Brandão et al., 2014) and some authors suggests that these should not be included in hatching experiments because these empty chambers underestimate the hatching rates (Conde-Porcuna et al., 2011; Brandão et al., 2014; Paes et al., 2016). Thus, it is important that studies evaluating hatching rates consider the quantity of eggs within the ephippia to calculate the actual rate, or hatching may be considerably underestimated. However, ephippia with or without resting eggs inside are morphologically similar and difficult to distinguish. 
Some authors consider a few methods to know the exact number of resting eggs contained in ephippia before performing hatching tests. Some of them suggests using a pair of needles to open ephippia and select viable eggs (Caceres \& Tessier, 2003; Angeler et al., 2005; Davison, 1969; Caceres, 1998). Other authors observe the presence of eggs using an inverted microscope (Pérez-Martínez et al., 2013). However, such methods may require time and great skills. Therefore, some authors are suggesting the importance of ephippia decapsulation, using techniques as the whitening with exposing ephippium of Daphnia species to sodium hypochlorite (Pancella \& Stross, 1963; Haghparast et al., 2012; Paes et al., 2016). Haghparast et al. (2012) exposed the eggs of $D$. magna to sodium hypochlorite at a concentration of $1 \%$ for 5 minutes to check their response to light. La et al. (2009) used hypochlorite at $4 \%$ for 20 minutes to decapsulate D. galeata ephippia. Still, Paes et al. (2016) were the first to study in detail the hatching rate of resting eggs in two tropical Daphnia species (D. laevis and D. ambigua) exposed to different concentrations of sodium hypochlorite, and at different time periods. In this study the authors concluded that the expositure of ephippia to $2 \%$ sodium hypochlorite for 20 minutes did not adversely affect neonate survival, and also allowed viewing of the eggs in all ephippia.

The effect of resting eggs decapsulation under hatching rate is still unknown. Regardless of the method, the use of hypochlorite and needles destroys the protective barrier formed by melanin pigmentation, which may be crucial during the development process of the embryo contained in resting eggs (Retnaningdyah \& Ebert, 2016). Considering this vast researching field, we evaluated in this study the hatching rates of Daphnia laevis ephippia collected in a tropical reservoir (Belo Horizonte, Minas Gerais, Brazil), aiming to compare the rates between resting eggs decapsulated and intact ephippia under controlled conditions. We hypothesized that decapsulating resting eggs would alter hatching rates, due to increased exposure to environmental factors such as light and dehydration.

\section{Material and Methods}

\subsection{Sampling, analysis and experiment}

The ephippia used on the experiment were caught from the sediment of Pampulha reservoir, a eutrophic freshwater system located in the city of Belo Horizonte, Brazil (S 1955’ 09”, W 435 $\left.56^{\prime} 47^{\prime \prime}\right)$.
The sediment was collected during the Spring of 2017 , and it was kept cold $\left(4^{\circ} \mathrm{C}\right)$ and dark until processing in laboratory. To collect the sample, a dredge with capacity for 10 centimeters-depth of substrate was used, and then the sediment was kept in plastic bags for posterior analysis. We only used Daphnia laevis Birge 1878, a very abundant Cladocera present in the reservoir. At the sediment of the studied reservoir, only ephippia of this species are usually found (Maia-Barbosa et al., 2003). No resting eggs or ephippia from other species were present in the analyzed sediment. To be sure that they were the only ephippia on the experiment, we separated them from the sediment, and we later identified and counted with the support of a stereoscope microscope.

To remove the ephippia from the substrate, we used the floatation and manual clam method, avoiding the use of the typical sugar flotation method to minimize risks of sugar influence on the ephippia wall. The ephippia collected was separated in two: a group with decapsulated resting eggs where the each ephippium was opened manually using needles, one by one, then visually checked if they were still undamaged; and a control group, with the whole ephippia — intact and without opening. Each group had a sample of 20 random ephippia with six replicates (ponds), totalizing 120 ephippia for each group.

At the end of the experiment, each ephippium of the control group was also opened to quantify the number of resting eggs, and the number of eggs added to the number of individuals born would give us the information about the total resting eggs at the beginning of the experiment (number of eggs at the beginning = number of hatchlings + number of eggs at the end). The amount of resting eggs found inside of each ephippium was noted and used to calculate the average of resting eggs per ephippia.

To start and interrupt diapause, many peculiar environmental variations may be included (Paes et al., 2016) and it affects ex situ studies, since all those conditions can't be reproduced in laboratories. To keep the study's standard, both groups were exposed to the same photoperiod and temperature conditions, in the same intensity: 12 hours photoperiod at $22^{\circ} \mathrm{C}$ for 30 days, immersed in approximately $10 \mathrm{~mL}$ of culture water (natural source: neutral $\mathrm{pH}$; hardness: $45-55$ mgCaCO3.L-1; dissolved oxygen: 6-7 mg. L- ${ }^{1}$; electric conductivity: 160-180 $\mu \mathrm{S} . \mathrm{cm}^{-}{ }^{1}$ ) each pond. The hatching was daily observed, the $D$. laevis neonates that emerged 
from the resting eggs were counted and all of them were removed from the pools day by day. The culture water was renewed periodically to avoid contamination by fungi.

\subsection{Data analysis}

We denominate "Actual Hatching Rates" those calculated from the total amount of resting eggs found inside the ephippia, and denominate "Misleading Hatching Rates" those calculated from the total amount of ephippia.

Two-way mixed model ANOVA was performed to test for the differences in the hatching timing among the treatments (fixed), correcting for the replicates (random factor). The effect of random factor was not significant $(P>0.05)$. All statistical analysis was performed in R software (R Core Team, 2017) and the data was initially verified as to ensure normality and homogeneity.

\section{Results}

We found significant differences in hatching rates between intact and decapsulated groups $(\mathrm{F} 1,10=7.791, \mathrm{p}=0.019)$ and in the hatching time $(\mathrm{F} 30,330=2.444, \mathrm{p}<0.001)$. The first hatchling in the intact group was observed on day 5 and in the decapsulated on day 6 . There were only two more days with hatchings in the decapsulated group (days 9 and 10), while for the intact there were another nine days with the maximum hatching occurred on day 12 (hatch rate $=1.35 \%$ ) and we observed hatching in this group until day 27. The daily hatch rates were low in both groups (Figure 1) and cumulative hatch rates throughout the experiment are shown in Figure 2.

The actual hatching rate was about 3.6 times higher in the intact ephippia group (22\%). As the number of eggs found in the groups (102-123 eggs) was quite equivalent to the ephippia number used in the experiment (120 ephippia), the misleading and actual hatching rates were very similar in this study (Table 1).

After opening the 120 ephippia from each group, a total of 102 eggs were found in the decapsulated group and 123 eggs in the intact group. In both groups, between 37 and $38 \%$ of ephippia were empty. Disregarding the empty ephippia and considering only the number of those that contained eggs inside, in the calculation we obtained an average of 1.4 eggs per ephippium for decapsulated group and of 1.6 eggs per ephippium for intact group (Table 1).

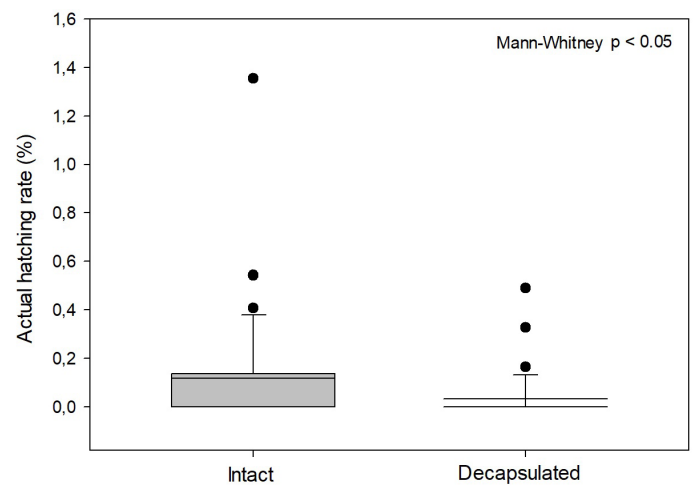

Figure 1. Hatching rates in decapsulated and intact groups (center line-mean, outer grey-5th/95th percentiles, bars- 95\% confidence level, black circles- outlier).

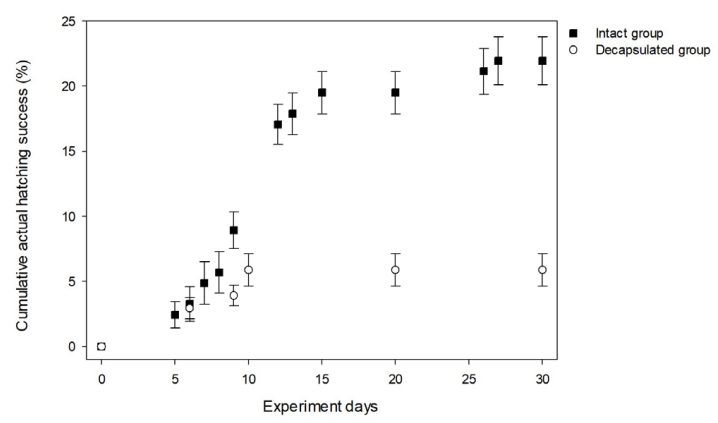

Figure 2. Cumulative hatching success over time for decapsulated and intact groups. Error bars indicates standard deviation.

Table 1. Comparison between decapsulated and intact groups.

\begin{tabular}{lcc}
\hline & $\begin{array}{c}\text { Decapsulated } \\
\text { group }\end{array}$ & $\begin{array}{c}\text { Intact } \\
\text { group }\end{array}$ \\
\hline Ephippia & 120 & 120 \\
Total eggs & 102 & 123 \\
Empty ephippia & 46 & 44 \\
Empty ephippia rate & $38 \%$ & $37 \%$ \\
Hatchling number & 6 & 27 \\
Misleading hatching rate & $5 \%$ & $23 \%$ \\
Actual hatching rate & $6 \%$ & $22 \%$ \\
\hline
\end{tabular}

\section{Discussion}

Our study showed that hatching rates were higher when the ephippia were kept intact, highlighting the importance of maintaining the outside capsule of the resting eggs in diapause studies. In addition to higher hatching rate, the group with intact ephippia showed births until 27 days of experiment, with a higher number of Daphnia born on day 12. In contrast, the group with eggs from the decapsulated ephippia presented births only until day 10 , even though these eggs 
seemed perfect after the cap removal. The absence of hatching in this group after ten days of removal of the capsule may be due to possible damage from the external environment that caused the total infeasibility of the eggs. The resting eggs are located in protuberances called egg chambers inside the ephippium, and that part is more melanised and sclerotised, providing more resistant to physical damage (Zaffagnini, 1987). It is known that the pigmented protective capsule ensures photo protection and studies have already demonstrated how important is the pigmentation to protect dormant embryos against ultraviolet radiation (Burtt Junior \& Gatz Junior, 1982; Majerus, 1998; Tucker et al., 1996). Gerrish \& Caceres (2003) proved that the intensity of the pigmentation in the ephippia is mainly a genetic factor, and this structure is darker when the females spend more energy in its production, heavily investing in the population's dormancy as a whole. These authors also suggested that ephippia's outside structure seems crucial for the embryo development, as there seems to be a mechanism of degradation associated to the growth of the new individuals inside the resting eggs: as long as the embryo develops, the ephippia becomes darker as well (Mellors 1975). So far, studies indicate that there is a perfect equilibrium between the ephippium pigmentation and the light entrance, once Paes et al. (2016) observed that hatching rates of $\mathrm{D}$. laevis in the dark were always lower than in light conditions, but magnifying too much the light access to the resting eggs, such as decapsulating, also triggered lower hatchings, as we observed.

In the present work, the rate variance between actual and misleading hatching was not significant because of the number of eggs found was coincidentally very close to the total number of ephippia, despite the high percentage of empty ephippia observed. However, an ephippium can have one, two or three eggs, and it has been documented that a large proportion of empty ephippia are usually found in experiments with different Daphnia species (Vaníčková et al., 2010; Conde-Porcuna et al., 2011; Ohtsuki et al., 2015; Paes et al., 2016; Brandão et al., 2019) and then the difference between actual and misleading hatching rate can be highly discrepant and doubtful. We advise further studies to consider actual hatching rates, opening each ephippium at the end of experiments to check total eggs, instead of basing statistics data on misleading hatching rate.

Even for intact ephippia group the observed hatch rates were low $(22 \%)$. Cáceres \& Tessier
(2003) suggested that laboratory experiments usually present higher ephippia hatching, once simulated biotic and abiotic factors are different from the original environment - where degradation and chemical damaged, for example, could happen more often due many unknown mechanisms that may not be perceived or easily reproduced in laboratories. However, laboratory hatch tests may not contain the necessary clues to the end of the dormancy having much lower hatch rates as in our study. Despite these issues, the undeniable fact is that diapause mechanisms vary a lot inside and between Daphnia populations (Cáceres \& Tessier, 2003), so other tropical studies like this one are highly recommended.

This study showed that decapsulation methods may compromise studies involving cladoceran ephippia. Thus, hatching tests performed with intact ephippia are more indicated, since it seems to show results that are closer to those that occur naturally in aquatic ecosystems, as the ephippia may indicate extra protection against the external factors for the embryos contained within. For better comprehension of the effects of laboratory chemicals used for decapsulation processes, such as sodium hypochlorite, on the embryo development, more studies are still required. In addition, the opening of the intact ephippia remaining after the hatch test can be a better methodology to know the percentage of empty ephippia and the average number of eggs per ephippia, also allowing the calculation of the actual hatching rate.

\section{Acknowledgements}

This study was supported by Conselho Nacional de Desenvolvimento Científico e Tecnológico (CNPq), Fundação de Amparo à Pesquisa do Estado de Minas Gerais (FAPEMIG) and Coordenação de Aperfeiçoamento de Pessoal de Nível Superior (CAPES). We would also like to thank the Laboratório de Limnologia, Ecotoxicologia e Ecologia Aquática (ICB - UFMG) team for all the support and shared knowledge, as well as the staff of the Brazilian Long-Term Ecological Research (LTER/UFMG, site 4) coordinated by Prof. Dr. Francisco Barbosa, UFMG.

\section{References}

ANGELER, D.G., MARTÍN, S. and MORENO, J.M. Daphnia emergence: a sensitive indicator of fire-retardant stress in temporary wetlands. Environment International, 2005, 31(4), 615-620. 
http://dx.doi.org/10.1016/j.envint.2004.10.015. PMid:15788202.

BAN, S. and MINODA, T. Hatching of diapause eggs of Eurytemora affinis (Copepoda: Calanoida) collected from lake-bottom sediments. Journal of Crustacean Biology, 1992, 12(1), 51-56. http://dx.doi. org/10.2307/1548718.

BRANDÁO, L.P.M., PAES, T.A.S.V., PUJONI, P., SILVA, M.I.B., OLIVEIRA, D.M., BARBOSA, F.A.R. and MAIA-BARBOSA, P.M. Ephippia cemetery in the sediment of a permanent tropical lake. Fundamental and Applied Limnology, forthcoming 2019.

BRANDÃO, L.P.M., PUJONI, D.G.F. and MAIABARBOSA, P.M. Seasonal dynamics of Daphnia laevis Birge, 1878 ephippia in a tropical lake with a description of a new methodology for in situ evaluation. Brazilian Journal of Biology = Revista Brasileira de Biologia, 2014, 74(3), 642 648. http://dx.doi.org/10.1590/bjb.2014.0069. PMid:25296213.

BRENDONCK, L. and DE MEESTER, L. Egg banks in freshwater zooplankton: evolutionary and ecological archives in the sediment. Hydrobiologia, 2003, 491(1-3), 65-84. http://dx.doi. org/10.1023/A:1024454905119.

BURTT JUNIOR, E.H. and GATZ JUNIOR, A.J. Color convergence: is it only mimetic? American Naturalist, 1982, 119(5), 738-740. http://dx.doi. org/10.1086/283948.

CÁCERES, C.E. and TESSIER, A.J. How long to rest: the ecology of optimal dormancy and environmental constraint. Ecology, 2003, 84(5), 1189-1198. http:// dx.doi.org/10.1890/0012-9658(2003)084[1189:HL TRTE]2.0.CO;2.

CÁCERES, C.E. and TESSIER, A.J. To sink or swim: variable diapause strategies among Daphnia species. Limnology and Oceanography, 2004, 49(4), 13331340.

CÁCERES, C.E. Interspecific variation in the abundance, production, and emergence of Daphnia diapausing eggs. Ecology, 1998, 79(5), 1699-1710. http://dx.doi. org/10.1890/0012-9658(1998)079[1699:IVITAP 12.0.CO;2.

CONDE-PORCUNA, J.M., VALDÉS, F.J., ROMO, S. and PÉREZ-MARTÍNEZ, C. Ephippial and subitaneous egg abortion: relevance for an obligate parthenogenetic Daphnia population. Journal of Limnology, 2011, 70(1), 69-75. http://dx.doi. org/10.4081/jlimnol.2011.69.

DAVISON, J. Activation of the ephippial egg of Daphnia pulex. The Journal of General Physiology, 1969, 53(5), 562-575. http://dx.doi.org/10.1085/jgp.53.5.562. PMid:5814069.

FRYER, G. Diapause, a potent force in the evolution of freshwater crustaceans. Hydrobiologia, 1996, 320(13), 1-14. http://dx.doi.org/10.1007/BF00016800.
GERRISH, G.A. and CÁCERES, C.E. Genetic versus environmental influence on pigment variation in the ephippia of Daphnia pulicaria. Freshwater Biology, 2003, 48(11), 1971-1982. http://dx.doi. org/10.1046/j.1365-2427.2003.01136.x.

GILBERT, J.J. and WILLIAMSON, C.E. Sexual dimorphism in zooplankton (Copepoda, Cladocera, and Rotifera). Annual Review of Ecology and Systematics, 1983, 14(1), 1-33. http://dx.doi. org/10.1146/annurev.es.14.110183.000245.

GILBERT, J.J. Structure, development and induction of a new diapause stage in rotifers. Freshwater Biology, 1995, 34(2), 263-270. http://dx.doi. org/10.1111/j.1365-2427.1995.tb00886.x.

HAGHPARAST, S., SHABANI, A., SHABANPOUR, B. and HOSEINI, S.A. Hatching requirements of Daphnia magna Straus, 1820, and Daphnia pulex Linnaeus, 1758, diapausing eggs from Iranian populations in vitro. Journal of Agricultural Science and Technology, 2012, 14(4), 811-820.

HAIRSTON JUNIOR, N.G., HANSEN, A.M. and SCHAFFNER, W.R. The effect of diapause emergence on the seasonal dynamics of a zooplankton assemblage. Freshwater Biology, 2000, 45(2), 133-145. http://dx.doi.org/10.1046/j.13652427.2000.00386.x

HAIRSTON JÚNIOR, N.G., VAN BRUNT, R.A., KEARNS, C.M. and ENGSTROM, D.R. Age and survivorship of diapausing eggs in a sediment egg bank. Ecology, 1995, 76(6), 1706-1711. http:// dx.doi.org/10.2307/1940704.

IGLESIAS, C., BONECKER, C., BRANDÁO, L., CRISPIM, M.C., ESKINAZI-SANT'ANNA, E.M., GERHARD, M., LAÇO PORTINHO, J., MAIA-BARBOSA, P., PANARELLI, E. and SANTANGELO, J.M. Current knowledge of South American cladoceran diapause: A brief review. International Review of Hydrobiology, 2016, 101(3-4), 91-104. http://dx.doi.org/10.1002/iroh.201501825.

INNES, D.J. and SINGLETON, D.R. Variation in allocation to sexual and asexual reproduction among clones of cyclically parthenogenetic Daphnia pulex (Crustacea: Cladocera). Biological Journal of the Linnean Society. Linnean Society of London, 2000, 71(4), 771-787. http://dx.doi.org/10.1006/ bijl.2000.0474.

JERSABEK, C.D. and SCHABETSBERGER, R. Resting egg production and oviducal cycling in two sympatric species of alpine diaptomids (Copepoda: Calanoida) in relation to temperature and food availability. Journal of Plankton Research, 1995, 17(11), 2049-2078. http://dx.doi.org/10.1093/ plankt/17.11.2049.

KING, C.E. and SNELL, T.W. Density-dependent sexual reproduction in natural populations of the rotifer Asplanchna girodi. Hydrobiologia, 1980, 73(1-3), 149-152. http://dx.doi.org/10.1007/ BF00019440. 
KLEIVEN, O.T., LARSSON, P. and HOBæK, A. Sexual reproduction in Daphnia magna requires three stimuli. Oikos, 1992, 65(2), 197-206. http://dx.doi. org/10.2307/3545010.

LA, G.H., JEONG, H.G., KIM, M.C., JOO, G.J., CHANG, K.H. and KIM, H.W. Response of diapausing eggs hatching to changes in temperature and the presence of fish kairomones. Hydrobiologia, 2009, 635(1), 399-402. http://dx.doi.org/10.1007/ s10750-009-9913-7.

LARSSON, P. Intraspecific variability in response to stimuli for male and ephippia formation in Daphnia pulex. In: V. KOŘÍNEK and D.G. FREY. Biology of Cladocera. Netherlands: Springer, 1991, pp. 281-290.

MAIA-BARBOSA, P.M., ESKINAZI-SANT'ANNA, E.M., VALADARES, C.F. and PESSOA, G.C.D. The resting eggs of zooplankton from a tropical, eutrophic reservoir (Pampulha Reservoir, southeast Brazil). Lakes and Reservoirs: Research and Management, 2003, 8(34), 269-275. http://dx.doi.org/10.1111/j.14401770.2003.00229.x.

MAJERUS, M. Melanism: evolution in action. Oxford: Oxford University Press, 1998.

MELLORS, W.K. Selective predation of ephippial Daphnia and the resistance of ephippial eggs to digestion. Ecology, 1975, 56(4), 974-980. http:// dx.doi.org/10.2307/1936308.

MÖST, M., OEXLE, S., MARKOVÁ, S., AIDUKAITE, D., BAUMGARTNER, L., STICH, H.B., WESSELS, M., MARTIN-CREUZBURG, D., SPAAK, P. Population genetic dynamics of an invasion reconstructed from the sediment egg bank. Molecular ecology, 2015, 24(16), 4074-4093.

OHTSUKI, H., AWANO, T., TSUGEKI, N.K., ISHIDA, S., ODA, H., MAKINO, W. and URABE, $\mathrm{J}$. Historical changes in the ecosystem condition of a small mountain lake over the past 60 years as revealed by plankton remains and Daphnia ephippial carapaces stored in lake sediments. PLoS One, 2015, 10(3), 1-19. http://dx.doi.org/10.1371/journal. pone.0119767. PMid:25757090.

PAES, T.A., RIETZLER, A.C., PUJONI, D.G. and MAIA-BARBOSA, P.M. High temperatures and absence of light affect the hatching of resting eggs of Daphnia in the tropics. Anais da Academia Brasileira de Ciências, 2016, 88(1), 179-186. http:// dx.doi.org/10.1590/0001-3765201620140595. PMid:26871496.

PAES, T.A.S.V., RIETZLER, A.C., BRITO, L.F., MAIA-BARBOSA, P.M. Efeitos de sinais de alarme e de predação na produção e eclosão de ovos de resistência de Daphnia laevis Birge, 1878 de uma lagoa tropical. In: T.A.S.V. PAES. Diapausa em Daphnia de ambientes aquáticos tropicais permanentes: fatores que influenciam a formação e eclosão de ovos de resistência. Belo Horizonte: UFMG, 2015, pp. 52-63.

PANCELLA, J.R. and STROSS, R.G. Light induced hatching of Daphnia resting eggs. Chesapeake
Science, 1963, 4(3), 135-140. http://dx.doi. org/10.2307/1350746.

PÉREZ-MARTÍNEZ, C., MORENO-LINHARES, E., JIMÉNEZ, L. and CONDE-PORCUNA, J.M. Emergence pattern and hatching cues of Daphnia pulicaria (Crustacea, Cladocera) in an alpine lake. Hydrobiologia, 2013, 707(1), 47-57. http://dx.doi. org/10.1007/s10750-012-1404-6.

PIJANOWSKA, J. and STOLPE, G. Summer diapause in Daphnia as a reaction to the presence of fish. Journal of Plankton Research, 1996, 18(8), $1407-$ 1412. http://dx.doi.org/10.1093/plankt/18.8.1407.

PORTINHO, J.L., NIELSEN, D.L., DARE, L., HENRY, R., OLIVEIRA, R.C. and BRANCO, C.C.Z. Mixture of commercial herbicides based on 2, 4-D and glyphosate mixture can suppress the emergence of zooplankton from sediments. Chemosphere, 2018, 203(2018), 151-159.

R CORE TEAM. R: A language and environment for statistical com-puting. Vienna: R Foundation for Statistical Computing, 2017.

RETNANINGDYAH, C. and EBERT, D. Bleach solution requirement for hatching of Daphnia magna Resting Eggs. Journal of Tropical Life Science, 2016, 6(3), 136-141. http://dx.doi.org/10.11594/ jtls.06.03.01.

ŚLUSARCZYK, M. Predator-induced diapause in Daphnia. Ecology, 1995, 76(3), 1008-1013. http:// dx.doi.org/10.2307/1939364.

STROSS, R.G. Light and temperature requirements for diapause development and release in Daphnia. Ecology, 1966, 47(3), 368-374. http://dx.doi. org/10.2307/1932977.

TUCKER, A.D., YEOMANS, S.R. and GIBBONS, J.W. Shell strength of mud snails (Ilyanassa obsolete) may deter foraging by diamondback terrapins (Malaclemys terrapin). American Midland Naturalist, 1996, 138(1), 224-229. http://dx.doi.org/10.2307/2426670.

VANDEKERKHOVE, J., DECLERCK, S., BRENDONCK, L., CONDE-PORCUNA, J.M., JEPPESEN, E. and MEESTER, L.D. Hatching of cladoceran resting eggs: temperature and photoperiod. Freshwater Biology, 2005, 50(1), 96-104. http:// dx.doi.org/10.1111/j.1365-2427.2004.01312.x.

VANÍČKOVÁ, I., SEDA, J. and PETRUSEK, A. The stabilizing effect of resting egg banks of the Daphnia longispina species complex for longitudinal taxon heterogeneity in long and narrow reservoirs. Hydrobiologia, 2010, 643(1), 85-95. http://dx.doi. org/10.1007/s10750-010-0126-x.

ZAFFAGNINI, F. Reproduction in Daphnia. Memorie dell'Istituto Italiano di Idrobiologia, 1987, 45, 245 284. 